\title{
Serum globulin changes in patients with craniocerebral trauma
}

\author{
L. AUER AND W. PETEK \\ From the Universitätsklinik für Neurochirurgie, and Institut für Medizinische Biochemie, \\ Graz, Austria
}

SYNOPSIS Investigations of serum total protein, albumin, alpha-1, alpha-2, alpha-2M, beta- and gamma-globulin changes are reported in 48 patients with craniocerebral trauma. Only alpha- 2 and alpha-2M globulins showed important variations, the first rising to three to four times normal values $(112 \%$ on average) and directly correlating with the amount of tissue lesions. Alpha-2M changes were rather irregular with a tendency to severe decrease during the first days in patients with a bad prognosis. Reasons for non-regular changes of alpha-2M are discussed. Alpha-1 globulin showed a similar though less marked increase. Gamma globulin, on average, was diminished in the first week.

Two main interests led us to investigate serum globulin changes in brain-injured patients. One was to see whether alpha-2 globulin variations described by different authors (Schmidt et al., 1953, 1954; Schumacher and Schlumberger, 1963) in other traumatic or postoperative conditions, were the same in neurosurgical patients suffering from an injury. The other reason originated from our own experimental investigations (Auer, 1975). Brain tissue of cats examined two hours after craniocerebral trauma had shown a significantly increased content of proteolytic enzymes, especially of neutral proteases. Disturbances of membrane function due to proteolytic activity (Janoff and Scherzer, 1968; Steinbuch and Audran, 1974) could enable these enzymes to reach the blood stream and change the level of their inhibitors. One of the main serum globulins with protease inhibitor function besides alpha-1 antitrypsin is the alpha-2M globulin (Kunz et al., 1973; Barrett, 1974; Barrett and Starkey, 1974; Heimburger, 1974; Steinbuch and Audran, 1974; Travis et al., 1974). It transpired that this globulin showed various alterations in different conditions such as an increase in cirrhosis of the liver (Cleve, 1967) and nephrotic syndrome (Hitzig et al., 1965; Steines and Mehl, 1966; Cleve 1967) and a decrease in irreversible shock (Ohlsson, 1974), situations of increased vascular permeability (Steinbuch and Audran, 1974), or postoperative haemorrhage (Fischer, 1972). Its production is genetically determined ( $\pi$ gene) (Travis et al., 1974 genetic faults being linked with pulmonary and hep atic diseases (Laurell and Eriksson, 1963). To verif our initial results, which were published recently (Auer and Petek, 1976), we increased the number of patients, because alpha-2 and alpha-2M changes ha proved interesting.

\section{METHODS}

The investigations were performed in 48 patients, 44 men and four women. They consisted of serum total protein, albumin, alpha, beta, gamma, and alpha-2M globulin determination, the latter employing Manzini's radial immunodiffusion method. ${ }^{1}$ The patients were separated into two groups, the first (42) containing those suffering from severe head injury with large brain contusions (EEG focus) and intracranial haematomas. Six patients had only skull fractures without or with only a little brain tissue lesion (no EEG focus). As standard values (mean values of the population) we used the data of Heilmeyer (1961).

Total protein: $72.5 \mathrm{~g} / 1 \pm 10 \%$, albumin $41 \mathrm{~g} / 1 \pm$ $15 \%$, alpha-1 globulin $3 \mathrm{~g} / 1 \pm 30 \%$, alpha-2 globulin $4.5 \mathrm{~g} / 1 \pm 30 \%$, beta globulin $8 \mathrm{~g} / 1 \pm 25 \%$, gamma globulins $12.5 \mathrm{~g} / 1 \pm 20 \%$, alpha-2M globulin $2.4 \mathrm{~g} / 1$ $\pm 37 \%$. 


\section{RESULTS}

From the relative values, absolute globulin and albumin contents were calculated from the total protein and evaluated in percentage deviation from the population mean value (Fig. 1).

The arithmetical mean values from these percentage deviations of total protein, albumin, and globulins, including 42 patients with severe head injury, are shown in the Table and Fig. 1. Compared with our previous study on 31 patients (Auer and Petek, 1976), total protein was unchanged and moved around
$72.5 \mathrm{~g} / 1$, down to $-6 \%$ at the maximum. Albumin, too, remained within the normal range $( \pm 15 \%)$, rising to $+10 \%$ in the first three days then decreasing to $-15 \%$ within ten more days. After a rapid descent to $-17 \%$ on the first day, beta globulins also remained normal. Gamma globulins showed a very marked diminution in the first week, slowly returning towards the mean value in the second week: $-27 \%$ on the third day was unequivocally below the normal range as well as $-26 \%$ on the fourth.

Significant changes in all patients were typical for alpha-2 globulins, increasing continuously in the

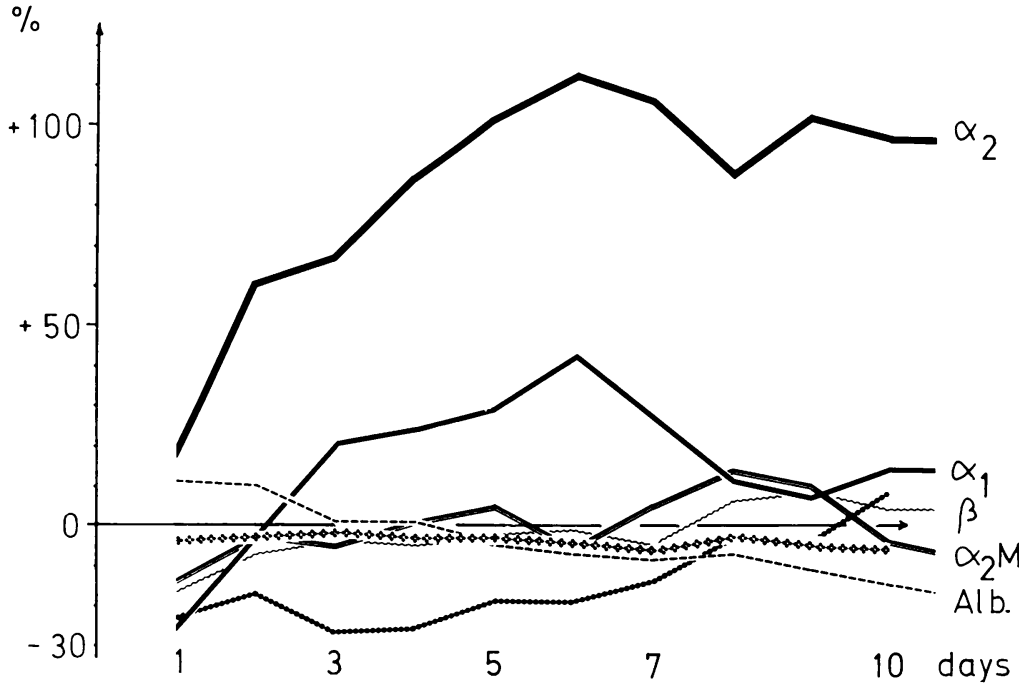

FIG. 1 Random mean value deviation from the population mean values of serum proteins within the first 10 days after severe head injury. $0:$ mean value of the population. Dotted line: gammaglobulin. Square line: total protein. Marked increase of alpha-2 globulins, mild alterations of alpha-1 and gamma, the other values remaining within their normal range. Day one means the day of trauma.

TABLE

ARITHMETICAL MEAN VALUES OF PERCENTAGE DEVIATION OF INDIVIDUAL ABSOLUTE PROTEIN VALUES IN FIRST 10 DAYS AFTER TRAUMA

\begin{tabular}{|c|c|c|c|c|c|c|c|c|c|c|}
\hline & \multicolumn{10}{|c|}{ Days after trauma } \\
\hline & 1 & 2 & 3 & 4 & 5 & 6 & 7 & 8 & 9 & 10 \\
\hline $\begin{array}{l}\text { Total protein } \\
\pm \% \text { of mean } \\
\text { Albumin }\end{array}$ & $-4(10)$ & $-3(22)$ & $-2(21)$ & $-3(24)$ & $-3(18)$ & $-4(19)$ & $-6(24)$ & $-3(14)$ & $-5(15)$ & $-6(13)$ \\
\hline $\begin{array}{l}\% \text { of mean } \\
\text { Alpha- } 1 \text { globulin }\end{array}$ & $+11(13)$ & $+10(22)$ & $+1(20)$ & $+1(23)$ & $-4(18)$ & $-7(19)$ & $-9(24)$ & $-7(14)$ & $-11(15)$ & $-15(13)$ \\
\hline $\begin{array}{l} \pm \% \text { of mean } \\
\text { Alpha-2 globulin }\end{array}$ & $-26(13)$ & $-2(22)$ & $+20(21)$ & $+24(23)$ & $+29(18)$ & $+42(19)$ & $+27(24)$ & $+11(14)$ & $+7(15)$ & $+14(13)$ \\
\hline $\begin{array}{l} \pm \% \text { of mean } \\
\text { Alpha- } 2 \mathrm{M} \text { globulin }\end{array}$ & $+19(9)$ & $+61(22)$ & $+66(21)$ & $+87(23)$ & $+102(18)$ & $+112(18)$ & $+106(24)$ & $+88(13)$ & $+103(15)$ & $+97(13)$ \\
\hline $\begin{array}{l} \pm \% \text { of mean } \\
\text { Beta globulin }\end{array}$ & $-16(7)$ & $-1(21)$ & $-5(17)$ & $+1(19)$ & $+5(15)$ & $-6(15)$ & $+5(16)$ & $+14(14)$ & $+10(15)$ & $-4(10)$ \\
\hline $\begin{array}{l} \pm \% \text { of mean } \\
\text { Gamma globulin }\end{array}$ & $-17(8)$ & $-7(22)$ & $-4(21)$ & $-5(23)$ & $-2(18)$ & $-1(18)$ & $-5(24)$ & $+6(14)$ & $+8(15)$ & $+4(13)$ \\
\hline$\doteqdot \%$ of mean & $-23(8)$ & $-17(22)$ & $-27(21)$ & $-26(23)$ & $-19(18)$ & $-19(18)$ & $-14(24)$ & $-3(14)$ & $-5(15)$ & $+10(13)$ \\
\hline
\end{tabular}

Day 1 means the day of the trauma. In parentheses: number of patients for the mean value. 
course of the first week to a maximum of $+112 \%$ on the sixth day, then remaining around $+100 \%$ during the second week. Alpha-1 globulins demonstrated the same changes as alpha-2, but to a less marked degree. They began with an initial decrease during the first days that gave place to an augmentation up to $42 \%$ on the sixth day. In the course of the second week it showed a mild increase within the normal range.

Alpha-2M globulins, on average, did not show any marked changes. The greater number of patients in this new series revealed that the decrease in the first days after a severe trauma was not as great as we measured earlier (Auer and Petek, 1976). Normal values followed an initial decrease on the first day.

Sometimes individual curves of alpha-2 and alpha$2 \mathrm{M}$ globulins showed a countercurrent development. Very high and very low alpha-2M values could occur without necessarily 'indicating' a bad or good prognosis for the patient.

Formation of different patient groups, however, throws more light on the characteristics of alpha-2M globulin changes in these patients. These special results will be given in another paper. They should indicate that there was a tendency in patients with severe or lethal outcome towards decreased levels in the first days. Sometimes, though rarely, they were normal or even increased.

Other individual changes such as an increase of beta globulins were short lived and irregular, statistically levelled towards the mean by an increasing number of patients. The only regular and very marked observation was the augmentation of alpha-2 globulins, which correlates directly with the extent and severity of brain tissue lesion. Large contusions of the brain with multiple bone fractures, eventually ending with a lethal outcome or post-traumatic apallic syndrome, always resulted in an increase of alpha-2 globulin to 200-300\% (Fig. 2A). Moderate increase was, in most cases, followed by a quicker recovery and a better outcome for the patient (Fig. 2C). Slight increase of alpha-2 globulin values occurred in six patients. All of them recovered completely within a month (Fig. 2B).

\section{DISCUSSION}

In comparison with our previous study (Auer and Petek, 1976), alpha-2 globulin levels remained steadily very high after severe craniocerebral trauma, changes worthy of further investigation after a series with such a great number of patients. One of the most important points in these observations is undoubtedly the definitely positive correlation between alpha globulin augmentation and the degree of brain tissue lesion as well as the final outcome for the patient. Schumacher and Schlumberger (1963) made similar

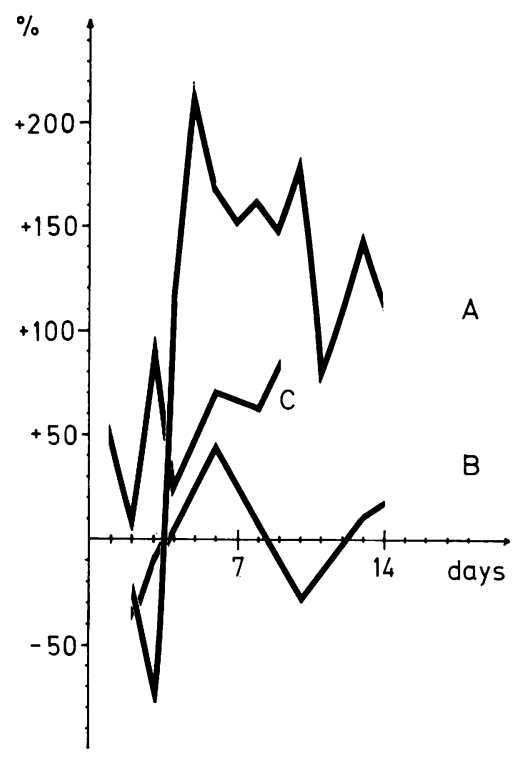

FIG. 2 Curves of alpha-2 globulins over twळ weeks (nine days) of three patients with different. degrees of severity of trauma. A: severe closed 응 brain injury with multiple contusions, after long क coma with acute mid-brain syndrome, develop $\overrightarrow{\mathrm{D}}$ 을 ment of post-traumatic apallic syndrome in which $\vec{Z}$ the patient more or less remained. B: skult fracture without brain contusion. Some days comatose, signs of apallic syndrome. Complete 을 recovery within one month. C: curve of alpha-市 globulin of a 16 year old patient with acute sub $=\overrightarrow{+}$ dural haematoma and brain-contusion on the same side. Globulin increase up to $+130 \%$ at the maximum. The patient had a short apallic phase of about one week then recovered within two months with little residual defects. Day one means the day of trauma.

observations in gynaecological patients and ascribed them to changes in haptoglobin levels, the latter originating in increased haemoglobin degradation. Our results once more emphasise that alpha 2-M globulin changes show no direct correlation with the marked alpha-2 globulin increase. This means that the alterations in alpha- 2 and alpha-2M globulin in this study appear to have a different origin. As alpha-2M globulin decreased in the first days after a craniocerebral trauma rather than increased it gives the first indication of an augmented need for inhibitory activity in this situation. Investigations of Barrett (1974) and Ohlsson (1974) indicate 
that the alpha-2M globulin, which is effective against all lysosomal endopeptidases, is decreased or missing when high levels of proteolytic activity exist in the plasma, the complex being eliminated very rapidly (Blåtrix et al., 1973; Barrett and Starkey, 1973; Barrett, 1974). Other observers were unable to measure a decrease of alpha-2M globulins in situations where it was expected: Adham et al. (1972) saw reduced trypsin binding capacity in patients with acute pancreatitis, but unchanged alpha-2M globulin levels. Farrow and Baar (1973) reported a fivefold increase of extravascular alpha-2M globulin as soon as one hour after burn injuries, alpha-2M levels remaining relatively normal throughout. These results support our observations of irregular alpha-2M globulin changes, indicating that (1) there is an increased proteolytic activity in the plasma in our patients, and (2) synthesis of alpha-2M globulin appears to be accelerated very soon. Therefore, alpha-2M globulin levels indicate such changes only in a very imprecise way. Single values do not necessarily correlate with a clinical situation nor with survival, and vascular permeability can produce largely differing plasma levels of alpha-2M globulins from one minute to another without it auguring important prognostic changes for the patient's outcome.

For the moment, it is impossible to say whether alterations of the coagulatory system (plasminogenplasmin) (Roboz, 1971; Barrett and Starkey, 1973; Heimburger, 1974; Steinbuch and Audran, 1974), neutral leucocyte proteinase (Ohlsson, 1971) and proteases of injured tissue (Auer et al., 1974; Auer, 1975) are connected with these changes.

One can say, in conclusion, that our observations disclose two different results:

(1) increase of alpha-2 globulin in the coma of two weeks after craniocerebral trauma, correlating positively with the dimensions of the tissue lesion;

(2) in the same situation changes of alpha- $2 \mathrm{M}$ globulins showing a tendency towards decrease in the first days, probably due to their main function -namely, the inhibition of plasma proteases.

\section{REFERENCES}

Adham, N. F., Dyce, B., and Haverback, B. J. (1972). Trypsin-binding alpha-2-macroglobulin in patients with acute pancreatitis. Gastroenterology, 62, 365-372.

Auer, L. (1975). Beitrag zur Pathophysiologie des posttraumatischen Hirnödems. Wiener klinische Wochenschrift, 17, 556-560.

Auer, L., and Petek, W. (1976). Serumproteinveränderungen bei Patienten mit Schädelhirn-Trauma-Vergleich zwischen Alpha-2 und Alpha-2M Globulinabweichungen. Acta Neurochirurgica, 33, 301-309.
Auer, L., Wendt, P., Huber, P., and Blümel, G. (1974). Investigations of proteolytic enzyme activity after experimental craniocerebral trauma. New Aspects of Trasylol Therapy, 7, 225-235.

Barrett, A. J. (1974). Inhibitors of lysosomal proteinase. In Proteinase Inhibitors, pp. 574-580. Edited by $\mathbf{H}$. Fritz, H. Tschesche, L. J. Greene, and E. Truscheit. Springer: Berlin.

Barrett, A. J. and Starkey, P. M. (1973). The interaction of the alpha-2-macroglobulin with proteinases. Biochemical Journal, 133, 709-724.

Barrett, A. J., and Starkey, P. M. (1974). The unique nature of the interaction of alpha-2-macroglobulin with proteinases. In Proteinase Inhibitors, pp. 72-77. Edited by $H$. Fritz, H. Tschesche, L. J. Greene, and E. Truscheit. Springer: Berlin.

Blåtrix, C., Amouch, P., Drouet, J., and Steinbuch, M. (1973). Plasma clearance of human antiproteinase proteinase complexes. (In French). Semaine des Hôpitaux de Paris, suppl. Pathologie et Biologie, 21, 11-14.

Cleve, H. (1967). Quantitative Variationen von SerumGlycoproteinen bei Pathologischen Prozessen. Klinische Wochenshcrift, 45, 1051-1060.

Farrow, S. P., and Baar, S. (1973). The metabolism of alpha-2-macroglobulin in mildly burned patients. Clinical Chimica Acta, 46, 39-48.

Fischer, M. (1972). Verhalten menschlicher Thromboinhibitoren (Alpha-2-Macroglobulin und Antithrombin III) während und nach chirurgischen und gynäkologischgeburtschilfichen Eingriffen. Folia Haematologia, 98, 397-407.

Heilmeyer, L. (1961). Lehrbuch der Inneren Medizin, p. 377. Springer: Berlin.

Heimburger, N. (1974). Biochemistry of proteinase inhibitors from human plasma: a review of recent development. In Proteinase Inhibitors, pp. 14-22. Edited by $\mathbf{H}$. Fritz, H. Tschesche, L. J. Greene, and E. Truscheit. Springer: Berlin.

Hitzig, W. H., Auricchio, S., and Benninger, J. L. (1965). Clearance spezifischer Plasmaproteinfraktionen bei Kindern. Klinische Wochenschrift, 43, 1154-1166.

Janoff, A., and Scherzer, T. (1968). Mediators of inflammation in leukocyte lysosomes. 9. Elastinolytic activity in granules of human polymorphonuclear leucocytes. Journal of Experimental Medicine, 128 1137-1151.

Kunz, S., Herschlein, H. J., Steichele, D. F., and Kidess, E. (1973). Verhalten physiologischer Inhibitoren der Blutgerinnung und Fibrinolyse während der Schwangerschaft, unter Geburt und im Wochenbett. Medizinische Welt, 24, 1266-1269.

Laurell, C. B., and Eriksson, S. (1963). The electrophoretic alpha-1-globulin pattern of serum in alpha-1-antitrypsin deficiency. Scandinavian Journal of Clinical Laboratory Investigation, 15, 132-140.

Ohlsson, K. (1971). Neutral leucocyte proteases and elastase inhibited by plasma alpha-1-antitrypsin. Scandinavian Journal of Clinical and Laboratory Investigation, 28, 251-253. 
Ohlsson, K. (1974). Interaction between endogenous proteases and plasma protease inhibitors in vitro and in vivo. In Proteinase Inhibitors, pp. 96-105. Edited by H. Fritz, H. Tschesche, L. J. Greene, and E. Truscheit. Springer: Berlin.

Roboz, E. (1971). Determination of serum proteins and polysaccharides. Archives of Neurology and Psychiatry (Chic.), 32, 536-543.

Schmidt, C., Matiar, H., and Geinert, F. (1953). Veränderungen der Serumproteine nach Hirnoperationen und anderen Eingriffen am ZNS. Deutsche Zeitschrift für Nervenheilkunde, 170, 119-136.

Schmidt, C., Matiar, H., and Geinert, F. (1954). Über die Wirkung der pharmakologischen Hibernation auf die Serumproteinveränderungen nach Hirnoperationen. Deutsche Zeitschrift fur Nervenheilkunde, 171, 507-524.
Schumacher, G., and Schlumberger, H. D. (1963). Über Veränderungen der Alpha-Globuline des Serums. Deutsche Medizinische Wochenschrift, 88, 645-651.

Steinbuch, M., and Audran, R. (1974). Biology and pathology of plasma proteinase inhibitors. In Proteinase Inhibitors, pp. 78-95. Edited by H. Fritz, H. Tschesche, L. J. Greene, and E. Truscheit. Springer: Berlin.

Steines, W. J., and Mehl, W. J. (1966). The elevation of alpha-2-macroglobulin and trypsin-binding activity in nephrosis. Journal of Laboratory and Clinical Medicine, 67, 559-565.

Travis, J., Johnson, D., and Pannell, R. (1974). Properties of human alpha-1 antitrypsin. In Proteinase Inhibitors, pp. 31-39. Edited by H. Fritz, H. Tschesche, L. J. Greene, and E. Truscheit. Springer: Berlin. 